\title{
Role of IgG subclass response to outer-membrane proteins in inhibiting adhesion of Pseudomonas aeruginosa to epithelial cells
}

\author{
MARY MORRIN and D. J. REEN* \\ Children's Research Centre, Our Lady's Hospital for Sick Children, Crumlin, Dublin 12
}

\begin{abstract}
Summary. The IgG subclass response to the major outer-membrane proteins (OMPs) of Pseudomonas aeruginosa was investigated in 11 cystic fibrosis (CF) patients and 10 healthy controls. Inhibition of adhesion of $P$. aeruginosa to buccal epithelial cells by the IgG serum fractions from the $\mathrm{CF}$ patients has been established previously. The CF patients demonstrated marked heterogeneity in their individual IgG subclass response to pseudomonal OMPs. The predominant IgG1 and IgG4 responses were directed towards OMPs F, H2 and, with IgG1 only, to protein I. Proteins of 42 and $46 \mathrm{kDa}$ primarily elicited an IgG2 response but some patients produced IgG4 antibodies. The IgG3 response varied from very weak in some patients to a strong reaction with proteins D2, E, G and I in others. The range of antigenspecific IgG subclass responses was similar in CF patients whose IgG fractions strongly inhibited the adherence of $P$. aeruginosa to epithelial cells and in those whose fractions gave only weak inhibition of adherence. There was no indication that an antibody response towards any particular OMP was implicated in the inhibition of bacterial adherence. Thus, the IgG subclass response to OMPs did not exert a significant effect on adherence when investigated in isolation, but may possibly play some role in combination with other processes.
\end{abstract}

\section{Introduction}

Two of the major components of the Pseudomonas aeruginosa outer membrane are lipopolysaccharide (LPS) and a series of outer-membrane proteins (OMPs). The primary functions of the OMPs include pore formation, ${ }^{1}$ structure determination and maintenance, ${ }^{2,3}$ and specific substrate transport. ${ }^{4}$ The OMP profile of $P$. aeruginosa is highly conserved among serotype reference strains, ${ }^{5}$ clinical isolates ${ }^{6}$ and environmental isolates. ${ }^{7}$

The humoral immune response to the OMPs of $P$. aeruginosa in cystic fibrosis (CF) patients has already been studied. A correlation between the presence of antibody to mucoid exopolysaccharide and antibody to OMPs has been reported. ${ }^{8}$ Moreover, antibodies to OMPs have been detected, by immunoblotting, early in pseudomonal infection in CF patients. ${ }^{9}$ The prevalence of the immune response to the OMPs in CF has generated interest in their possible potential as vaccine candidates ${ }^{10}$ and the efficacy of the major OMPs F and I as vaccines in murine models has already been described. ${ }^{11,12}$

It has been demonstrated that the adherence of an Escherichia coli strain to epithelial cells was inhibited

Received 17 Aug. 1992; revised version accepted 4 June 1993. * Correspondence should be sent to Dr D. J. Reen. by outer membranes ${ }^{13}$ and that isolated outer membranes acted as competitive inhibitors of adherence. ${ }^{14}$ Moreover, we have shown that IgG antibody from CF patients' sera inhibits the adherence of $P$. aeruginosa to buccal epithelial cells and that each of the IgG subclasses contributed to this inhibition. ${ }^{15}$ In this report, we describe studies of the IgG subclass response to the OMPs of $P$. aeruginosa as related to the ability of these antibodies to inhibit bacterial adhesion.

\section{Materials and methods}

\section{Bacterial strain and growth conditions}

A non-mucoid clinical isolate of $P$. aeruginosa from a CF patient was used throughout. This strain was maintained at $4^{\circ} \mathrm{C}$ on tryptone soya agar. For isolation of OMPs, the organism was grown in tryptone soya broth at $37^{\circ} \mathrm{C}$ for $40 \mathrm{~h}$, allowing the cells to reach stationary phase.

\section{Patients}

All CF patients investigated in this study were adults with chronic $P$. aeruginosa infection. Sera from age-matched, healthy individuals were used as controls. 


\section{Adhesion model system}

The method used was similar to that described previously. ${ }^{15,16}$ Briefly, buccal epithelial cells from healthy volunteers were coated on to microtitration plates and incubated overnight at $37^{\circ} \mathrm{C}$ to dry. After fixing by treatment with glutaraldehyde $0.25 \%$ for $10 \mathrm{~min}$ at room temperature (RT), the cell monolayers were incubated with bovine serum albumin (BSA) $1 \%$ in phosphate-buffered saline (PBS) for $1 \mathrm{~h}$ at RT to block non-specific adherence. $P$. aeruginosa suspensions, pre-incubated for $1 \mathrm{~h}$ at $37^{\circ} \mathrm{C}$ with PBS or with IgG preparations from $\mathrm{CF}$ patients or controls, were then added to the buccal epithelial cell-coated wells for $1 \mathrm{~h}$ at $37^{\circ} \mathrm{C}$. After fixing with glutaraldehyde $0.25 \%$, and blocking with BSA $1 \%$, bound bacteria were detected immunologically by the addition of a $P$. aeruginosa-specific monoclonal antibody (Serotec, Kidlington, Oxford) and incubation for $1 \mathrm{~h}$ at RT. Horseradish peroxidase (HRP)-conjugated rabbit anti-mouse IgG (Dako, High Wycombe, Bucks) was added to the wells for $1 \mathrm{~h}$ at RT, followed by orthophenylene diamine substrate. The absorbance of each well at $450 \mathrm{~nm}$ was read after exactly $30 \mathrm{~min}$ with a Microplate Reader (Bio-tek, Winoski, VT, USA).

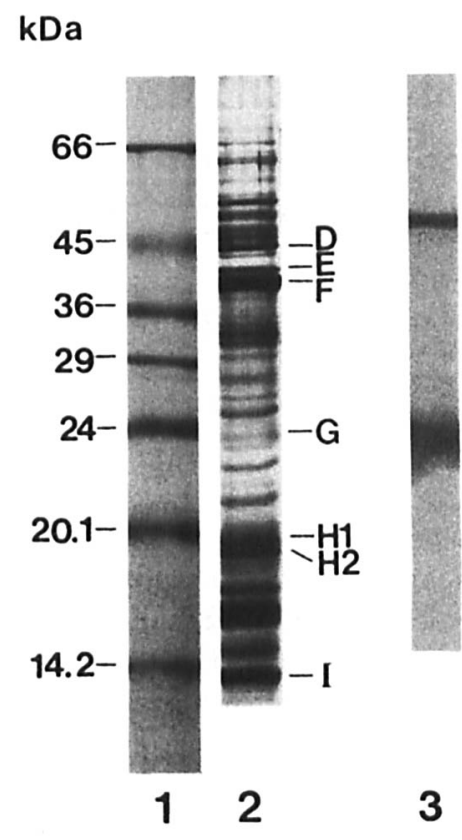

Fig. 1. SDS-PAGE profile of silver-stained OMPs of $P$. aeruginosa. Lane 1, molecular mass standards; 2, OMP fraction-major identified protein bands are listed on the right hand side; $\mathbf{3}$, an immunoblot developed with anti-protein $\mathrm{F}$ and anti-protein $\mathrm{H} 2$ MAbs, confirming identification of these components.

\section{IgG isolation}

The IgG fractions of CF and control sera were separated by Protein G-Sepharose (Pharmacia, Uppsala, Sweden) chromatography. The serum samples were applied to columns containing $1 \mathrm{ml}$ of the gel, washed with $0.02 \mathrm{M}$ sodium phosphate buffer, $\mathrm{pH} 7 \cdot 8$, and eluted with $0 \cdot 1 \mathrm{M}$ glycine, $\mathrm{pH} 2 \cdot 8$.

\section{OMP isolation}

Membranes were prepared essentially according to the method of Hancock and Nikaido. ${ }^{17} P$. aeruginosa cultures were harvested by centrifugation at $12000 \mathrm{~g}$ for $15 \mathrm{~min}$ after growth under the conditions described above. After washing with $30 \mathrm{~mm}$ Tris- $\mathrm{HCl}$ buffer, $\mathrm{pH} 8.0$, the combined cell pellets were resuspended in $25 \mathrm{ml}$ of sucrose $20 \%$ in $30 \mathrm{~mm}$ Tris- $\mathrm{HCl}$ buffer, $\mathrm{pH} 8.0$, containing $1 \mathrm{mg}$ each of pancreatic DNAase and RNAase. The suspension was maintained at $4{ }^{\circ} \mathrm{C}$ for all subsequent steps. The cells were ruptured by sonication and hen egg lysozyme $2 \mathrm{mg}$ was added to the mixture, followed, after $10 \mathrm{~min}$, by $100 \mu \mathrm{M}$ phenylmethylsulphonylfluoride. After removal of cell debris by centrifugation at $10000 \mathrm{~g}$ for $10 \mathrm{~min}$, the supernate was decanted and diluted with $14 \mathrm{ml}$ of the above Tris buffer. Approximate 7-ml volumes of the suspension were layered carefully on to a sucrose step gradient composed of a lower step of $3 \mathrm{ml}$ of sucrose $70 \% \mathrm{w} / \mathrm{v}$ and an upper step of $18 \mathrm{ml}$ of sucrose $15 \%$ $\mathrm{w} / \mathrm{v}$, both in the Tris buffer. After centrifugation at $183000 \mathrm{~g}$ for $1 \mathrm{~h}$ at $4^{\circ} \mathrm{C}$, the bottom $4-\mathrm{ml}$ amounts were removed from each tube and pooled. A 3-ml volume of this membrane fraction was layered on to a second sucrose density step gradient. The bottom step consisted of $4 \mathrm{ml}$ of sucrose $70 \% \mathrm{w} / \mathrm{v}$ and successive upper steps of $7 \mathrm{ml}$ each of sucrose $64 \%, 58 \%, 52 \%$ $\mathrm{w} / \mathrm{v}$, all in the Tris buffer. After centrifugation at $183000 \mathrm{~g}$ overnight at $4{ }^{\circ} \mathrm{C}$, four bands were observed. Each was removed, dialysed against distilled water for $24 \mathrm{~h}$, and concentrated by lyophilisation. The bottom two fractions contained the OMPs and the upper two contained mixed outer and inner membranes and purified inner membranes, respectively.

\section{SDS-PAGE and Western blotting}

OMPs were separated by SDS-PAGE by the method of Laemmli ${ }^{18}$ with a resolving gel $12.5 \%$ and stacking gel $3.0 \%$ in an Atto (Atto Corporation, Tokyo, Japan) mini-gel system. Samples were boiled for $10 \mathrm{~min}$ in a $\beta$ mercaptoethanol-containing sample buffer before application to the gel at a concentration of $5 \mu \mathrm{g}$ of protein/well. Electrophoresis was at $25 \mathrm{~mA}$ and $150 \mathrm{~V}$. An SDS-7 mol. wt marker kit (Sigma) was used for molecular mass estimations. This contained $\alpha$-lactalbumin (14200), soybean trypsin inhibitor (20100), trypsinogen (24000), carbonic anhydrase (29000), glyceraldehyde-3-phosphate dehydrogenase (36000), egg albumin (45000) and bovine serum albumin (66000). Gels were either stained with silver, ${ }^{19}$ or electroblotted on to nitrocellulose according to the method of Towbin et $a l^{20}$ In the latter case, protein transfer to nitrocellulose was completed after $2 \mathrm{~h}$ in a 
I

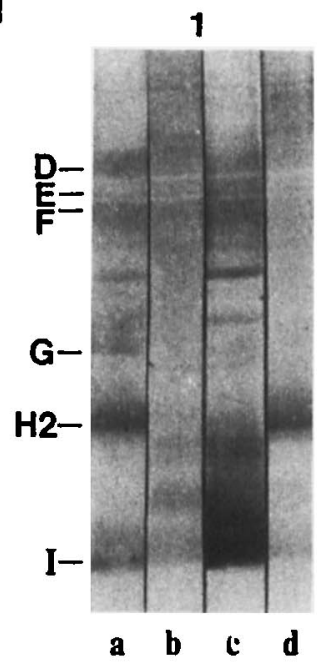

2



3

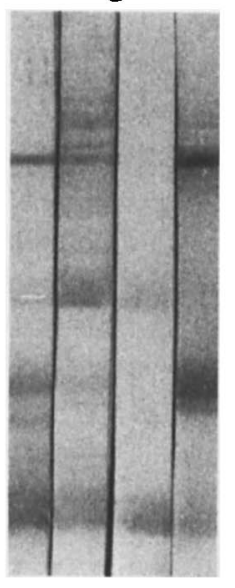

a b c d

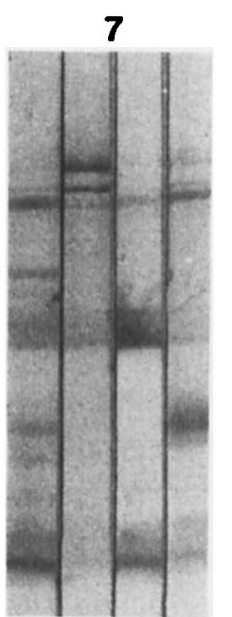

a b c d

II

9

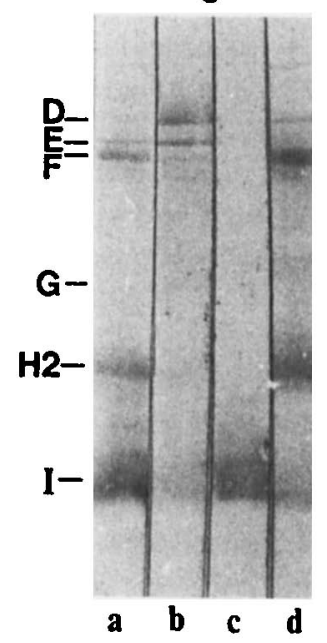

10

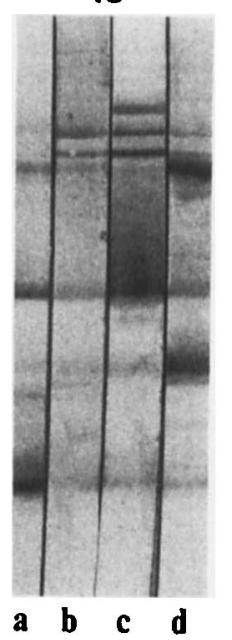

Fig. 2. Immunoblots demonstrating the reaction of IgG subclass antibodies from CF patients with OMPs of $P$. aeruginosa. Representative immunoblots from patients whose sera strongly inhibited adhesion of $P$. aeruginos $a$ to buccal epithelial cells (nos. 1, 2,3,7) are shown in panel I and those from patients whose sera weakly inhibited adhesion (nos. 9, 10) are shown in panel II. Strips a, b, c and d illustrate the IgG1, IgG2, IgG3 and IgG4 subclass responses, respectively. The major protein bands are listed on the left hand side.

Pharmacia LKB Novablot semi-dry blotting box at a constant current of $250 \mathrm{~mA}$. Visualisation of the proteins on the nitrocellulose was with reversible Ponsceau S stain. The nitrocellulose blots were cut into individual strips, each representing one lane from the original gel, and incubated with $0 \cdot 1 \mathrm{M}$ PBS, containing Tween $200.05 \%$, (PBS-T), to block non-specific binding. PBS-T was used as diluent in all subsequent steps, which were performed at RT with gentle shaking. The $\mathrm{IgG}$ fractions from $\mathrm{CF}$ or control sera $(0.7 \mathrm{mg} / \mathrm{ml})$ were incubated with the strips for $1 \mathrm{~h}$, after which the strips were washed in PBS, and incubated with either anti-IgG1 (Clone HP6001; Unipath, Basingstoke, Hants.), anti-IgG2 (Clone HP6014; Binding Site, Birmingham), anti-IgG3 (Clone HP6095; Janssen, Beerse, Belgium) or antiIgG4 (Clone SK-44; Sigma) monoclonal antibodies (MAbs) for $1 \mathrm{~h}$. Subsequently, the blots were washed in PBS and incubated for $1 \mathrm{~h}$ with HRP-conjugated rabbit anti-mouse IgG (Dako). Protein-antibody interactions were visualised with 3-amino-9-ethylcarbazole (AEC) substrate. OMPs F and $\mathrm{H} 2$ were identified with specific MAbs for these proteins, kindly donated by R. E. W. Hancock.

\section{Results}

\section{$O M P$ profiles of $P$. aeruginosa}

The OMPs of $P$. aeruginosa were isolated by sucrose density centrifugation and separated by SDS-PAGE. The bands representing the major OMPs were assigned as D2 (45 kDa), E (42 kDa), F (40 kDa), G (24 kDa), $\mathrm{H} 2(19.5 \mathrm{kDa})$ and $\mathrm{I}(13 \mathrm{kDa})$ (fig. 1). The most prominent was protein $\mathrm{F}$. Additional unidentified 
bands were visualised by silver staining. The identification of proteins $\mathrm{F}$ and $\mathrm{H} 2$ was confirmed with specific MAbs (fig. 1).

\section{IgG subclass response to OMPs}

The IgG subclass response of the CF patients and controls to the individual OMPs was investigated by immunoblotting. Representative blots, demonstrating the diversity in response observed amongst the $\mathrm{CF}$ patients are presented in fig. 2.

Panel I of this figure shows results for patients whose IgG fractions strongly inhibited adhesion of $P$. aeruginosa to buccal epithelial cells. IgG1 antibodies from each of these patients reacted with proteins $\mathrm{F}, \mathrm{H} 2$ and I. A weak IgGl antibody response to protein $G$ was also observed, and a $29-\mathrm{kDa}$ protein elicited an IgG1 response in two of the patients. The IgGl response of Patient 2 was very weak, giving only faint reactions with proteins $\mathrm{D} 2, \mathrm{E}$ and $\mathrm{F}$. The IgG2 response amongst these patients was predominantly directed towards the proteins putatively identified as D2 and E, and varied in intensity amongst the individual patients. In Patients 2, 3 and 7, a weak IgG response towards protein $\mathrm{G}$ was observed and a very faint reaction with protein $F$ was observed for each of the CF patients. IgG3 antibody responses varied quite substantially amongst these patients, ranging from very weak in Patients 2 and 3, to a strong response to proteins D2, E, G and I in Patient 1. The strong reaction with proteins $G$ and I was also observed with material from Patient 7 and a distinct 29-kDa band was visualised only with this fraction from Patient 1. Each of the patients whose IgG fractions strongly inhibited adhesion of $P$. aeruginosa, demonstrated a strong IgG4 antibody response to protein $\mathrm{H} 2$ but gave a weak IgG4 response to proteins D2 and E. The antiprotein $\mathrm{F}$ IgG4 response was strong in Patients 3 and 7, but weak in Patients 1 and 2.

Representative blots from two of the four CF patients whose IgG fractions had little ability to inhibit adhesion of $P$. aeruginosa to epithelial cells are presented in panel II of fig. 2. Heterogeneity of antibody response was also evident amongst these patients. IgG1 anti-F, - $\mathrm{H} 2$ and -I antibody responses were evident in each patient although those to the former two proteins were weak in Patient 10. An IgG1 response to protein $\mathrm{G}$ was also seen in Patient 10. IgG2 antibodies were directed primarily towards proteins D2 and $E$ but those from Patient 10 also showed a very faint reaction with proteins $F$ and $G$. The $\operatorname{IgG} 3$ antibody response varied considerably amongst the patients. Notably, Patient 10 had a strong $\operatorname{IgG} 3$ reaction towards proteins $\mathrm{D} 2, \mathrm{E}$ and $\mathrm{G}$ and an unidentified $55-\mathrm{kDa}$ protein. The IgG4 response was quite uniform amongst these patients, being primarily directed towards proteins $\mathrm{F}$ and $\mathrm{H} 2$, with only weak reactions to proteins $\mathrm{D} 2, \mathrm{E}$ and $\mathrm{G}$.

IgG preparations from the control sera did not react with any of the OMP bands, except that a weak reaction was observed in four controls with proteins D2 and E.

\section{Discussion}

The IgG subclass response to individual OMPs of $P$. aeruginosa has not been characterised previously. The heterogeneity of the subclass response is striking but is not so surprising, perhaps, when one considers the complex and variable immune response of these patients.

The silver staining method used to visualise OMPs detected bands other than the major OMPs; nevertheless, the IgG subclass antibodies were observed to interact only with the major OMPs. The IgGl and IgG4 responses were directed towards similar proteins, namely protein $F$ and the lipoprotein $\mathrm{H} 2$ in most patients, although with varying intensity. This observation is consistent with previous reports of the highly-conserved and highly- antigenic nature of these proteins. ${ }^{8,10,21}$ Although each of the CF patients may have been infected with a different strain of $P$. aeruginosa, each manufactured antibodies that reacted with OMPs $\mathrm{F}$ and $\mathrm{H} 2$ of the isolate used here. Proteins $\mathrm{F}$ and $\mathrm{H} 2$ are thought to be surface exposed in vivo, ${ }^{22}$ a fact that may contribute to their strong antigenicity. Lipoprotein I also evoked an IgGl response in each patient. Some sort of antibody response would have been expected here, as OMP I of $P$. aeruginosa is recognised as a vaccine candidate, and was found to cross-react with antisera raised against all serotype strains in an international antigenic typing scheme. ${ }^{12}$

The strong IgG2 and, in some cases, IgG4 responses to the protein bands at 42 and $46 \mathrm{kDa}$ have not been commented upon previously. These bands appear to represent proteins $\mathrm{D} 2$ and $\mathrm{E}$, based on molecular mass data. Molecular masses from $45 \mathrm{kDa}$ to $53 \mathrm{kDa}$ have also been reported for $P$. aeruginosa $\mathrm{H}$-antigen flagellins $^{23}$ but the presence of flagellar protein is unlikely because of the exhaustive isolation protocol. Where detected in immunoblots, these bands always appeared as a doublet, with none of the patients having an antibody response to only one component of the pair. It is possible that the two proteins detected here may not be two distinct species, but that the one of lower molecular mass may have been a degradation product or oxidised form of the other protein.

The $\mathrm{IgG} 2$ response of the panel of patients studied was generally limited to proteins D2 and E. This restricted response might be due to the reputed weakly stimulatory nature of protein antigens for $\operatorname{IgG} 2$ antibodies. ${ }^{24,25}$ However, there is a lack of consensus regarding the nature of the antigenic stimulation required for IgG2 antibody production, with some authors suggesting that the $\mathrm{IgG} 2$ response is partially restricted to polysaccharide antigens, ${ }^{26}$ whereas others have variation in response to these molecular species. $^{25,27}$ 
The IgG3 subclass response to OMPs demonstrated the greatest variation amongst patients. Low or undetectable levels of IgG3 and IgG2 antibodies have been reported in patients who were chronically exposed to protein antigens, ${ }^{25}$ and this may account for the lack of IgG3 antibodies in some patients studied.

The immune response of one patient (no. 2) was limited primarily to an anti-protein $\mathrm{H} 2 \mathrm{IgG} 4$ and an anti-protein D2 and E IgG2. This patient also had low total levels of $P$. aeruginosa-specific subclass antibodies ${ }^{15}$ nevertheless this individual's serum strongly inhibited adhesion of $P$. aeruginos $a$ to buccal epithelial cells. This implies that the low levels of pseudomonasspecific IgG antibodies present in this patient may be directed towards some moiety which is involved in adhesion, but not one of the OMPs.

\section{References}

1. Yoshihara E, Nakae T. Identification of porins in the outer membrane of Pseudomonas aeruginosa that form small diffusion pores. $J$ Biol Chem $1989 ; 264$ : 6297-6301.

2. Gottoh N, Wakabe H, Yoshihara E, Nakae T, Nishino T. Role of protein $F$ in maintaining structural integrity of the Pseudomonas aeruginosa outer membrane. $J$ Bacteriol 1989; 171 : 983-990.

3. Woodruff WA, Hancock REW. Pseudomonas aeruginosa outer membrane protein $\mathrm{F}$ : structural role and relationship to the Escherichia coli OmpA protein. J Bacteriol 1989; 171 : 3304-3309.

4. Sokol PA, Woods DE. Demonstration of an iron-siderophorebinding protein in the outer membrane of Pseudomonas aeruginosa. Infect Immunol 1983; 40: 665-669.

5. Mutharia LM, Nicas TI, Hancock REW. Outer membrane proteins of Pseudomonas aeruginosa serotype strains. $J$ Infect Dis 1982; 146: 770-779.

6. Mutharia LM, Hancock REW. Characterization of two surfacelocalized antigenic sites on porin protein $\mathrm{F}$ of Pseudomonas aeruginosa. Can J Microbiol 1985; 31: 381-386.

7. Hancock REW, Chan L. Outer membranes of environmental isolates of Pseudomonas aeruginosa. J Clin Microbiol 1986; 26: 2423-2424.

8. Hancock REW, Mouat ECA, Speert DP. Quantification and identification of antibodies to outer-membrane proteins of Pseudomonas aeruginosa in sera of patients with cystic fibrosis. J Infect Dis 1984; 149: 220-226.

9. Shand GH, Pedersen SS, Brown MRW, Høiby N. Serum antibodies to Pseudomonas aeruginosa outer-membrane proteins and iron-regulated membrane proteins at different stages of chronic cystic fibrosis lung infection. $J \mathrm{Med}$ Microbiol 1991; 34: 203-212.

10. Hedstrom RC, Pavlovskis OR, Galloway DR. Antibody response of infected mice to outer membrane proteins of Pseudomonas aeruginosa. Infect Immun 1984; 43: 49-53.

11. Gilleland HE, Gilleland LB, Matthews-Greer JM. Outer membrane protein $\mathrm{F}$ preparation of Pseudomonas aeruginosa as a vaccine against chronic pulmonary infection with heterologous immunotype strains in a rat model. Infect Immunol 1988; 56: 1017-1022.

12. Finke M, Duchêne M, Eckhardt A, Domdey H, von Specht BU. Protection against experimental Pseudomonas aeruginosa infection by recombinant $P$. aeruginosa lipoprotein I expressed in Escherichia coli. Infect Immun 1990; 58: 2241-2244.

13. Hancock REW, Wieczorek AA, Mutharia LM, Poole K. Monoclonal antibodies against Pseudomonas aeruginosa outer membrane antigens: isolation and characterization. Infect Immun 1982; 37: 166-171.
IgG antibodies from the sera of CF patients inhibit adherence of $P$. aeruginosa to buccal epithelial cells. ${ }^{15,16}$ However, the IgG subclass response to the OMPs of $P$. aeruginosa does not appear to influence the level of inhibition obtained, as these antibodies were detected both in sera that strongly inhibited the adhesion of $P$. aeruginosa and in sera that had little effect on the adhesion of the organism. An immune response to OMPs $\mathrm{F}$ and I would appear to provide some degree of protection against subsequent challenge, as has been shown in murine vaccination studies, ${ }^{27}$ but this protection does not seem to involve an anti-adhesion role. Bacterial adhesion to epithelial cells is a complex process involving many components. The outer-membrane components investigated here might play some role in a multifactorial adhesion system.

14. Mutharia LM, Hancock REW. Surface localization of Pseudomonas aeruginosa outer membrane porin protein $\mathrm{F}$ by using monoclonal antibodies. Infect Immun 1983; 42: 1027-1033.

15. Battershill JL, Speert DP, Hancock REW. Use of monoclonal antibodies to protein $\mathrm{F}$ of Pseudomonas aeruginosa as opsonins for phagocytosis by macrophages. Infect Immunol 1987; 55: 2531-2533.

16. Mutharia LM, Hancock REW. Monoclonal antibody for an outer membrane lipoprotein of the Pseudomonas fluorescens group of the family pseudomonadaceae. Int $J$ Syst Bacteriol 1985; 35: 530-532.

17. Sherman PM, Soni R. Adherence of vero cytotoxin-producing Escherichia coli of sterotype 0157: $\mathrm{H} 7$ to human epithelial cells in tissue culture: role of outer membranes as bacterial adhesins. J Med Microbiol 1988; 26: 11-17.

18. Sherman P, Cockerill F, Soni R, Brunton J. Outer membranes are competitive inhibitors of Escherichia coli O157:H7 adherence to epithelial cells. Infect Immun 1991; 59: $890-899$.

19. Morrin M, Reen DJ. Inhibition of the adherence of Pseudomonas aeruginosa to epithelial cells by IgG subclass antibodies. J Med Microbiol 1993; 39: 459-466.

20. Sexton M, Reen DJ. Characterization of antibody-mediated inhibition of Pseudomonas aeruginosa adhesion to epithelial cells. Infect Immun 1992; 60: 3332-3338.

21. Hancock REW, Nikaido H. Outer membranes of gram-negative bacteria XIX. Isolation from Pseudomonas aeruginosa PAOl and use in reconstruction and definition of the permeability barrier. J Bacteriol 1978; 136: 381-390.

22. Laemmli UK. Cleavage of structural proteins during the assembly of the head of the bacteriophage T4. Nature 1970; 227: $680-685$.

23. Oakley BR, Kirsch DR, Morris NR. A simplified ultrasensitive silver stain for detecting proteins in polyacrylamide gels. Anal Biochem 1980; 105: 361-363.

24. Towbin H, Staehelin T, Gordon J. Electrophoretic transfer of proteins from polyacrylamide gels to nitrocellulose sheets: Procedure and some applications. Proc Natl Acad Sci USA $1979 ; 76: 4350-5354$.

25. Shand GH, Pedersen SS, Tilling R, Brown MRW, Høiby N. Use of immunoblot detection of serum antibodies in the diagnosis of chronic Pseudomonas aeruginosa lung infection in cystic fibrosis. J Med Microbiol 1988; 27: 169-177.

26. Aronoff SC, Stern RC. Serum IgG antibody to outer membrane antigens of Pseudomonas cepacia and Pseudomonas aeruginosa in cystic fibrosis. J Infect Dis 1988; 157: $934-940$.

27. Speert DP, Dimmick JE, Pier GB, Saunders JM, Hancock REW, Kelly N. An immunohistochemical evaluation of Pseudomonas aeruginosa pulmonary infection in two patients with cystic fibrosis. Pediatr Res $1987 ; 22$ : 743-747. 
28. Allison JS, Dawson M, Drake D, Montie TC. Electrophoretic separation and molecular weight, characterization of Pseudomonas aeruginosa $\mathrm{H}$-antigen flaggellins. Infect Immun 1985; 49: 770-774.

29. Ruths S, Driedijk PC, Weening RS, Out TA. ELISA procedures for the measurement of IgG subclass antibodies to bacterial antigens. J Immunol Methods 1991; 140: 67-78.

30. Hamilton RG. Human IgG subclass measurements in the clinical laboratory. Clin Chem 1987; 33: 1707-1725.
31. Schur PH. IgG subclasses-a review. Ann Allergy 1987; 58: $89-86,99$.

32. Jefferis R, Kumararatne DS. Selective IgG subclass deficiency: quantification and clinical relevance. Clin Exp Immunol $1990 ; 81$ : 357-367.

33. Matthews-Greer JM, Robertson DE, Gilleland LB, Gilleland HE. Pseudomonas aeruginosa outer membrane protein $\mathrm{F}$ produced in Escherichia coli retains vaccine efficacy. Curr Microbiol 1990; 20: 171-175. 